\title{
Inhibition of lipid biosynthesis induces the expression of the pspA gene
}

\author{
Helmut Bergler, ${ }^{1}$ Dietmar Abraham, ${ }^{1}$ Heinrich Aschauer ${ }^{2}$ \\ and Friederike Turnowsky ${ }^{1}$
}

Author for correspondence: Friederike Turnowsky. Tel: +43316 3805620. Fax: +43316381548.

1 Institut für Mikrobiologie,
Karl-Franzens-Universität
Graz, Universitätsplatz 2,
A-8010 Graz, Austria
2 Sandoz Forschungsinstitut
GesmbH, Brunnerstraße
59, A-1235 Vienna, Austria

\begin{abstract}
Treatment of Escherichia coli with diazaborine strongly induces the synthesis of a $28 \mathrm{kDa}$ protein which is associated with the cytoplasmic membrane. The partial amino acid sequence proved that this protein is identical to the phage shock protein PspA. The kinetics of the expression of the pspA gene were determined in an $E$. coli strain which carried a pspA-lacz fusion in the chromosome. PspA synthesis is independent of the growth phase. It is, however, strongly induced when fatty acid biosynthesis is inhibited by diazaborine or cerulenin. Treatment with either compound also causes dosedependent inhibition of phospholipid biosynthesis whose degree correlates with the induction of PspA. Another cause of induction of PspA synthesis is treatment of $E$. coli with globomycin, which is an inhibitor of the processing of lipoproteins.
\end{abstract}

Keywords: Escherichia coli, $p s p A$ gene, lipid synthesis, diazaborine, globomycin

\section{INTRODUCTION}

Incubation of Escherichia coli cells with diazaborines, a group of boron-containing antibacterial compounds (Grassberger et al., 1984), leads to pleiotropic effects in the biosynthesis and composition of membrane constituents, i.e. inhibition of fatty acid-, phospholipid- and lipopolysaccharide biosynthesis (Turnowsky et al., 1989; Högenauer \& Woisetschläger, 1981). A specific effect on cell morphology that results in a retraction of the cytoplasmic membrane, predominantly at the poles of the treated cells, was also observed. The target of diazaborines is the envM gene product (Turnowsky et al., 1989), which we have recently shown to be the NADH-dependent enoyl-ACP reductase of E. coli (Bergler et al., 1994). Since the enzymic activity of the EnvM protein has been identified the corresponding gene has been renamed fabI (Bergler et al., 1994). When the E. coli mutant JP1111, which carries a temperature-sensitive fabI allele (Egan \& Russell, 1973), was incubated at the non-permissive temperature, similar effects on lipid biosynthesis and membrane morphology were observed. In addition, treatment of wild-type $E$. coli cells with the diazaborine derivative $2 \mathrm{~b} 18$ (Grassberger et al., 1984) at $30^{\circ} \mathrm{C}$ or incubation of the $f a b I$ mutant at the non-permissive temperature strongly induced the accumulation of a protein with an apparent molecular mass of $28 \mathrm{kDa}$ that is associated with the cytoplasmic membrane (Turnowsky et al., 1989).
In order to study the relationship of FabI to the $28 \mathrm{kDa}$ protein, we purified this protein and determined its partial amino acid sequence. We now show that this protein is identical to the recently described PspA protein (Brissette et al., 1991). PspA is induced in E. coli cells under extreme stress conditions, such as treatment with heat or ethanol, or by infection with filamentous bacteriophages (Brissette et al., 1990). Recently it was shown that PspA stimulates efficient protein export in $E$. coli (Kleerebezem \& Tommassen, 1993) and that expression of $p s p A$ is also induced under conditions that are known to interfere with protein translocation (Kleerebezem \& Tommassen, 1993; Carlson \& Silhavy, 1993). It is, however, a non-essential protein whose function in the cell under uninduced conditions is not fully understood. Inhibition of the fabI gene product by diazaborine is a novel cause for the induction of PspA. The expression of the protein correlates with inhibition of lipid biosynthesis.

\section{METHODS}

Bacterial strains, plasmids, and phages. Strains, plasmids, and phages are listed in Table 1. E. coli was grown in either $2 \times$ TY medium (Sambrook et al., 1989), in $2 \times$ TY medium with a low salt concentration $(0.05 \% \mathrm{w} / \mathrm{v})$, or in Minimal Medium A (Miller, 1972). Antibiotics were added when needed at the following concentrations: epicillin, $150 \mu \mathrm{g} \mathrm{ml}^{-1}$; kanamycin, $40 \mu \mathrm{g} \mathrm{ml}^{-1}$. For cloning procedures pUC118 (Vieira \& Messing, 1987) was used. Other plasmids are listed in Table 1. Chemicals and enzymes. Diazaborine, compound $2 \mathrm{~b} 18$, was 
Table 1. Bacterial strains, plasmids and phages

\begin{tabular}{|c|c|c|}
\hline Strain & Genotype, description or chatacteristics & Source or reference \\
\hline \multicolumn{3}{|l|}{ Escherichia coli } \\
\hline MC4100 & $\begin{array}{l}F^{-} \text {araD139D(argF-lac) U169 rpsL150 relA1 fbB5301 deoC1 ptsF25 } \\
\text { rbsR }\end{array}$ & T. Silhavy, Princeton, NJ, USA \\
\hline XL1 & $\begin{array}{l}\text { end } A 1 \text { usd } 17\left(b s d \mathrm{R}^{-}, \text {bsdM }\right. \\
\\
{\left[\mathrm{F}^{\prime} \text { pro } A B \text { lac } I^{q} Z \Delta \mathrm{M} 15, \operatorname{Tn} 10\left(\mathrm{Tet}^{\mathrm{R}}\right)\right]}\end{array}$ & Stratagene \\
\hline JP1111 & Hfr galE45 $\lambda^{-}$envM329(ts) relA1 spoT1 & $\begin{array}{l}\text { B. Bachmann, E. coli Genetic Stock } \\
\text { Center, Yale University }\end{array}$ \\
\hline $\mathrm{K} 125 \mathrm{~K}$ & $\mathrm{~F}^{-}$tre thi rps $L^{+} b s d \mathrm{R}^{-} b s d M^{+}$lac thr $\lambda^{-}$ & W. Goebel, Universität Würzburg, FRG \\
\hline MC1061 & $\begin{array}{l}b s d \mathrm{R} 2 b s d M^{+} b s d S^{+} \text {araD139 } \Delta(a r a-l e u)_{7697} \Delta(\text { lac })_{\mathrm{X} 74} \text { galE15 galK16 } \\
\quad r p s L\left(\mathrm{Str}^{\mathrm{R}}\right) \operatorname{mcr} A \operatorname{mcrB1}\end{array}$ & Casadaban \& Cohen $(1980)$ \\
\hline MC3 & MC4100 with integrated $\lambda \phi \mathrm{AD} 3, \mathrm{lac}^{+}$ & This work \\
\hline \multicolumn{3}{|l|}{ Plasmid } \\
\hline pRS591 & $\mathrm{Ap}^{\mathrm{R}}$, lac $Z^{\prime} Y A$ ori & Simons et al. (1987) \\
\hline R1-16 & $\mathrm{Km}^{\mathrm{R}}$ & Sandoz-Forschungsinstitut, Vienna \\
\hline pAD1 & $\begin{array}{l}\mathrm{Ap}^{\mathrm{R}}, 4.5 \mathrm{~kb} \text { EcoRI fragment from } \lambda 1 \mathrm{C} 2 \text {, carrying the } p s p \text { operon, in } \\
\text { pUC118 }\end{array}$ & This work \\
\hline pAD2 & $A \mathrm{p}^{\mathrm{R}}, 529$ bp EcoRI fragment (PCR amplified from pAD1) in pUC118 & This work \\
\hline pAD3 & $A p^{R}, 529$ bp EcoRI fragment (PCR amplified from pAD1) in pRS591 & This work \\
\hline \multicolumn{3}{|l|}{ Phages } \\
\hline$\lambda \mathrm{RS} 45$ & $\begin{array}{l}\text { Phage vector for the construction of single copy lac Z-fusion } \\
\text { prophages, } l a c^{-}\end{array}$ & Simons et al. (1987) \\
\hline$\lambda 1 \mathrm{C} 2$ & Recombinant $\lambda$ phage carrying the $p s p$ operon & Kohara et al. (1987) \\
\hline M13 & Filamentous ssDNA phage & \\
\hline $\mathrm{M} 13 \mathrm{KO} 7$ & $\mathrm{Km}^{\mathrm{R}}, \mathrm{p} 15 \mathrm{~A}$ ori & Vieira \& Messing (1987) \\
\hline$\lambda \phi \mathrm{AD} 3$ & $\begin{array}{l}\mathrm{Ap}^{\mathrm{R}} \text {, lac }{ }^{+} \text {; recombinant of } \lambda \text { RS45 and } \mathrm{pAD} 3 \text { carrying the lac } Z \text {-fusion } \\
\text { of } \mathrm{pAD} 3\end{array}$ & This work \\
\hline
\end{tabular}

described by Grassberger et al. (1984). Epicillin was from Biochemie. Kanamycin and cerulenin were from Sigma Nalidixic acid was purchased from Serva. Globomycin was a gift of Sankyo. Radiochemicals were obtained from DupontNEN. Enzymes for DNA work were from Boehringer $\mathrm{GmbH}$ and New England Biolabs Inc. For oligonucleotide synthesis the reagents were purchased from Applied Biosystems.

DNA work. Recombinant techniques were performed using the methods of Ausubel et al. (1987), Sambrook et al. (1989), or the protocols of the manufacturers. Transformations were dont: with the standard $\mathrm{CaCl}_{2}$ protocol. DNA from the recombinant: phage $\lambda 1 \mathrm{C} 2$ (Kohara et al., 1987) was isolated according to Silhavy et al. (1984) with E. coli K12 $5 \mathrm{~K}$ as the host. Singlestranded DNA was prepared from recombinant plasmids derived from pUC118 with the helper phage M13K07 (Vieira \& Messing, 1987). The sequence of the PCR-amplified DNA fragment was determined in the single-stranded form by the chain termination method of Sanger et al. (1977) using a. Sequenase Kit (USB).

Cloning procedures. The $p s p A$ operon on a $4.5 \mathrm{~kb}$ Eco Rl fragment from the recombinant phage $\lambda 1 \mathrm{C} 2$ (Kohara et al. 1987) was subcloned into appropriately cleaved pUC118. The recombinant plasmid was designated pAD1. The identity of $p s p A$ was confirmed by Southern hybridization of restriction enzyme digests of $\lambda 1 \mathrm{C} 2 \mathrm{DNA}$ with the $5^{\prime}$-endlabelled synthetic oligonucleotide PSP A2 as a probe according to standard procedures (Ausubel et al., 1987). The regulatory region of the psp operon was amplified from pAD1 as a 539 bp DNA fragment using PCR. Two specific oligonucleotides were synthesized according to the sequence published by Brissette et al. (1991). PSP A1 contains nucleotides 1 to 29 of the psp operon (5'

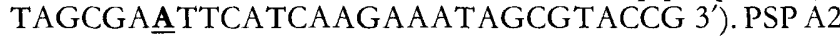
is complementary to nucleotides 517 to 539 which are located

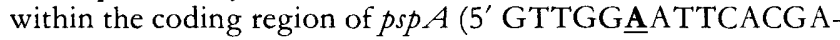
'TGTCGGCAA $3^{\prime}$ ). Both oligonucleotides contained a single base exchange in order to create an EcoRI restriction site to facilitate subsequent cloning; the exchanged bases are underlined. The PCR reaction was done with $P f u$ DNA polymerase (Stratagene) in a BIO-MED thermal cycler. The PCR product was purified from agarose gels with the US Bioclean MP Kit, cleaved with EcoRI and ligated into the appropriately cut pUC118 as well as the lacZ fusion vector pRS591 (Simons $e t$ al., 1987). The resulting recombinant plasmids were designated pAD2 and pAD3, respectively.

Construction of a single copy lacZ fusion. The plasmid-borne lac $Z$ fusion pAD3 was transferred to the $\lambda$ phage vector $\lambda$ RS45 (Simons et al., 1987) by homologous recombination. E. coli MC4100, carrying the multi-copy plasmid pAD3, was used as a host for the growth of $\lambda$ RS45. Recombinant phage were isolated from individual plaques on the basis of $\mathrm{Lac}^{+}$phenotype on $\mathrm{X}$ Gal plates. The lysate was used to infect E. coli MC4100 (Silhavy et al., 1984). Lysogens with the $p s p A-l a c Z$ fusion in the chromosome were selected as $\mathrm{Lac}^{+}$colonies on X-Gal plates and were designated E. coli MC3.

Phospholipid biosynthesis. E. coli $\mathrm{K} 125 \mathrm{~K}$ was grown in phosphate-free medium (Garen \& Levinthal, 1960) to early exponential phase $\left(\mathrm{OD}_{600} 0 \cdot 3\right)$. After addition of $10 \mu \mathrm{Ci}$ of $\left[{ }^{32} \mathrm{P}\right]$ orthophosphate the cultures were treated with cerulenin 
(50 or $100 \mu \mathrm{g} \mathrm{ml}^{-1}$ ) at $30^{\circ} \mathrm{C}$. At various time points the cells were harvested and extracted as described by Turnowsky $e t$ al. (1989). The radioactivity contained in aliquots of the chloroform phases was determined using scintillation spectroscopy.

Conjugation. The donor strain E. coli MC1061 carrying the plasmid R1-16 was mated for $45 \mathrm{~min}$ at $37^{\circ} \mathrm{C}$ with the recipient strain E. coli MC3. The ratio of donor to recipient was $1: 10$. After vigorous shaking, aliquots of the mating mixture were plated on X-Gal plates containing $40 \mu \mathrm{g}$ kanamycin $\mathrm{ml}^{-1}$. The transconjugants were selected for kanamycin resistance and $\mathrm{Lac}^{+}$phenotype and designated E. coli MC3 R1-16.

$\boldsymbol{\beta}$-Galactosidase activity. E. coli MC3 was grown in Minimal Medium A (Miller, 1972) at $30^{\circ} \mathrm{C}$ to early exponential phase $\left(\mathrm{OD}_{600} 0 \cdot 2-0 \cdot 3\right)$. The cultures were then treated with either diazaborine at 4 and $20 \mu \mathrm{g} \mathrm{ml}^{-1}$, cerulenin at 50 and $100 \mu \mathrm{g} \mathrm{ml}^{-1}$, globomycin at 10 and $50 \mu \mathrm{g} \mathrm{ml}^{-1}$, nalidixic acid at $40 \mu \mathrm{g} \mathrm{ml}^{-1}$, hydrogen peroxide at $70 \mu \mathrm{g} \mathrm{ml}^{-1}$, or naphthochinon at $100 \mu \mathrm{g} \mathrm{ml}^{-1}$. At various times the cultures were sampled and the $\beta$-galactosidase activity in the aliquots was determined according to Miller (1972). The activity was determined in duplicates and each experiment was performed at least two times. Results of representative experiments are shown. In the case of the infection with the filamentous phage M13, E. coli MC3 R1-16 was infected in early exponential phase with an M13 lysate at a multiplicity of 10 and the $\beta$-galactosidase activity determined at different times after infection as above.

Purification of the $\mathbf{2 8} \mathbf{~ k D a}$ protein. The conditional lethal fabI mutant E. coli JP1111 was grown in low salt $2 \times$ TY medium to early exponential phase $\left(\mathrm{OD}_{600} 0 \cdot 3\right)$. Subsequently the temperature was shifted to $42{ }^{\circ} \mathrm{C}$ for $5 \mathrm{~h}$. The cells were harvested by centrifugation and $4.5 \mathrm{~g}$ (wet weight) of cells were broken by sonication. The cell envelope fraction was collected by centrifugation for $60 \mathrm{~min}$ at $48000 \mathrm{~g}$ and extracted with $50 \mathrm{mM}$ Tris $/ \mathrm{HCl}, \mathrm{pH} 7 \cdot 6$, containing $2.5 \%(\mathrm{w} / \mathrm{v}$ ) Triton $\mathrm{X}-100$ for $30 \mathrm{~min}$ at room temperature. Insoluble material was removed and the supernatant fraction diluted with $50 \mathrm{mM}$ Tris $/ \mathrm{HCl}$, $\mathrm{pH} 7 \cdot 6$, to give a final Triton $\mathrm{X}-100$ concentration of $0.5 \%$ $(\mathrm{w} / \mathrm{v})$. All buffers for the subsequent purification steps contained $0.5 \%(\mathrm{w} / \mathrm{v})$ Triton X-100. Purification of the $28 \mathrm{kDa}$ protein was performed by fast protein liquid chromatography (FPLC, Pharmacia) using the following procedure. Aliquots of the supernatant, containing approximately $1 \mathrm{mg}$ total protein, were applied to a Mono Q column which had been equilibrated with $50 \mathrm{mM}$ Tris/ $\mathrm{HCl}$ buffer, $\mathrm{pH} 7 \cdot 6$, and the proteins were eluted with a linear salt gradient of $0-1 \mathrm{M} \mathrm{LiCl}$ in $50 \mathrm{mM}$ Tris $/ \mathrm{HCl}, \mathrm{pH} 7 \cdot 6$. Individual fractions were analysed on a $11 \%$ polyacrylamide-SDS gel. The $28 \mathrm{kDa}$ protein eluted between 350 and $375 \mathrm{mM} \mathrm{LiCl}$. Fractions containing the protein were pooled and dialysed against $50 \mathrm{mM}$ sodium acetate buffer, $\mathrm{pH} 5 \cdot 1$. Under these conditions the protein precipitated. The precipitate was collected by centrifugation and washed twice with $50 \mathrm{mM}$ sodium acetate buffer, $\mathrm{pH} 5 \cdot 1$. The pellet was finally dissolved in $50 \mathrm{mM}$ Tris $/ \mathrm{HCl}, \mathrm{pH} \mathrm{7 \cdot 6,0.5 \%}$ Triton $\mathrm{X}$ 100. After incubation for $60 \mathrm{~min}$ at $37^{\circ} \mathrm{C}$ the purified protein was unstable and cleaved into four distinct polypeptides. One of the cleavage products was subjected to amino acid sequence analysis.

Protein analysis. Protein concentrations were determined by the method of Bradford (1976), using bovine serum albumin as a standard. Cytoplasmic membrane proteins were prepared as described earlier (Turnowsky et al., 1989), except that the growth medium was $2 \times$ TY with low salt content. Proteins were separated on $11 \%$ polyacrylamide-SDS gels and stained with Coomassie Brilliant Blue.

\section{RESULTS}

\section{Induction, purification, and identification of the $28 \mathrm{kDa}$ protein}

Incubation of the temperature-sensitive fabI mutant $E$. coli JP1111 at the non-permissive temperature or with diazaborine at $30{ }^{\circ} \mathrm{C}$ leads to the inactivation of the FabI protein and the cessation of cell growth (Turnowsky et al., 1989). This effect is accompanied by the induction of a protein with an apparent molecular mass of $28 \mathrm{kDa}$ which is associated with the cytoplasmic membrane (Turnowsky et al., 1989; and Fig. 1, lanes 2 and 3). The induction is progressive and most prominent after 4 to $6 \mathrm{~h}$ incubation. Nalidixic acid induces the synthesis of conventional heatshock proteins. However, it did not induce the $28 \mathrm{kDa}$ protein, nor did it inhibit the induction by diazaborine (data not shown). The specific correlation between inhibition of FabI and induction of the $28 \mathrm{kDa}$ protein prompted us to purify this protein. Cell envelope fractions of $E$. coli JP1111, grown at the non-permissive temperature for $5 \mathrm{~h}$, were treated with Triton X-100 to solubilize cytoplasmic membrane proteins. Aliquots were applied to a Mono Q column and the proteins eluted with

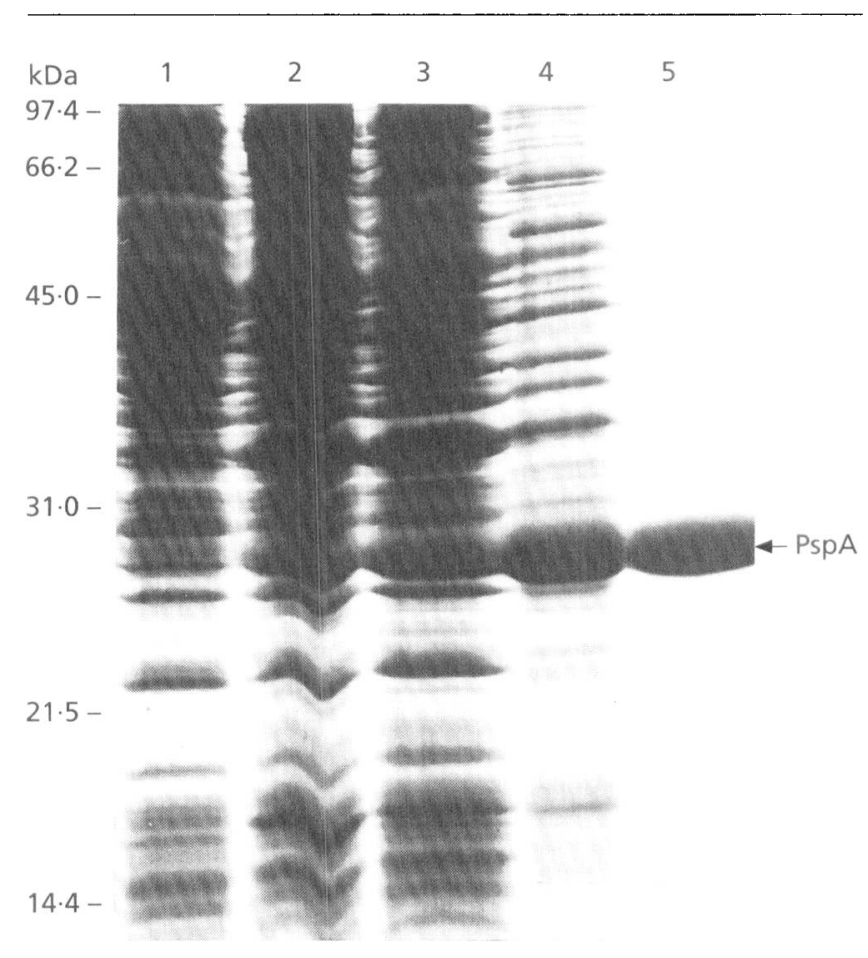

Fig. 1. Induction and purification of the PspA protein. Cytoplasmic membrane proteins isolated from the $\mathrm{fabl}$ ts mutant $E$. coli JP1111 which was grown at $30^{\circ} \mathrm{C}$ (lane 1 ), at $30^{\circ} \mathrm{C}$ in the presence of $20 \mu \mathrm{g}$ diazaborine $\mathrm{ml}^{-1}$ for $5 \mathrm{~h}$ (lane 2), and at $42{ }^{\circ} \mathrm{C}$ for $5 \mathrm{~h}$ (lane 3) were separated on an $11 \%$ polyacrylamide-SDS gel and stained with Coomassie Brilliant Blue. Lanes 4 and 5 show the enrichment of the $28 \mathrm{kDa}$ protein after FPLC-chromatography on a Mono Q column (lane 4) and after precipitation at $\mathrm{pH} 5.1$ (lane 5). The positions of the molecular mass standards and the $28 \mathrm{kDa}$ PspA protein are indicated. Total protein loaded on the gel was: $35 \mu \mathrm{g}$ on lanes 1 to $3,20 \mu \mathrm{g}$ on lane 4 , and $15 \mu \mathrm{g}$ on lane 5 . 
a linear gradient of lithium chloride as described in Methods. Individual fractions were analysed by SDSPAGE and those containing the $28 \mathrm{kDa}$ protein were pooled (Fig. 1, lane 4) and dialysed against sodium acetate buffer. At the acid $\mathrm{pH}$ of the buffer the $28 \mathrm{kDa}$ protein precipitated preferentially and, therefore, was enriched manyfold upon resuspension (Fig. 1, lane 5). The purified protein was unstable during incubation at $37^{\circ} \mathrm{C}$, probably due to a contaminating protease, and could be resolved into four distinct polypeptides by SDS-PAGE (data not shown). The $\mathrm{N}$-terminal amino acid sequence of one of the cleavage products was determined by Edman degradation and was found to be identical to amino acids $60-79$ of the sequence of the PspA protein of E. coli, which was published by Brissette et al. (1991). Although the derived molecular mass of PspA is $25.562 \mathrm{kDa}$ (Brissette et al., 1991) the protein showed an apparent molecular mass of approximately $28 \mathrm{kDa}$ in our SDS gel system.

\section{Cloning of the $E$. coli psp operon and construction of the pspA-lacZ fusion}

The $p s p$ operon has been mapped by $\mathrm{P} 1$ transduction and found to be closely linked to $p y r F$ and $r n b$ between min 28.3 and 29 of the E. coli chromosome (Brissette $e t$ al., 1991). Based on these data the $\lambda$ phage $1 C 2$ from the collection of Kohara et al. (1987) was expected to contain the $p s p$ operon. Phage DNA was prepared by standard procedures and cleaved with various restriction enzymes. The DNA fragments were separated on agarose gels and analysed by Southern hybridization. As a probe the specific oligonucleotide PSP A2 was used, which had been synthesized according to the published sequence of the psp operon. The $4.5 \mathrm{~kb}$ EcoRI fragment of the DNA from the recombinant $\lambda$ phage $1 \mathrm{C} 2$ hybridized with the oligonucleotide and thus carried the $p s p$ operon. The exact location of the operon could therefore be determined and has been assigned to coordinate 1384 of the Kohara $e t$ al. (1987) E. coli chromosomal map. The $4.5 \mathrm{~kb}$ EcoRI fragment, illustrated in Fig. 2, was cloned into the appropriately cleaved vector pUC118 and the recombinant plasmid designated pAD1. E. coli JP1111 cells that carried this multi-copy plasmid expressed the PspA protein to a high level when treated with diazaborine. The electrophoretic mobility was identical to that of the protein which was induced by incubation of plasmid-free E. coli cells with diazaborine (Fig. 3, lanes 1 and 2). Under non-inducing conditions PspA was only moderately expressed from pAD1 (Fig. 3, lane 3), probably because of the negative autoregulatory activity of PspA (Weiner $e t$ al., 1991).

The putative promoter region upstream of $p s p A$ was amplified by PCR with the use of the two specific primers PSP A1 and PSP A2 (Fig. 2). Single base exchanges in the sequences of both primers created EcoRI restriction sites which were used for subsequent cloning steps. The $539 \mathrm{bp}$ PCR product was cleaved with EcoRI and ligated into the lac $Z$ fusion vector $\mathrm{pRS} 491$ (Simons et al., 1987). The recombinant plasmid with the insert in the correct orientation was designated pAD3. This construction

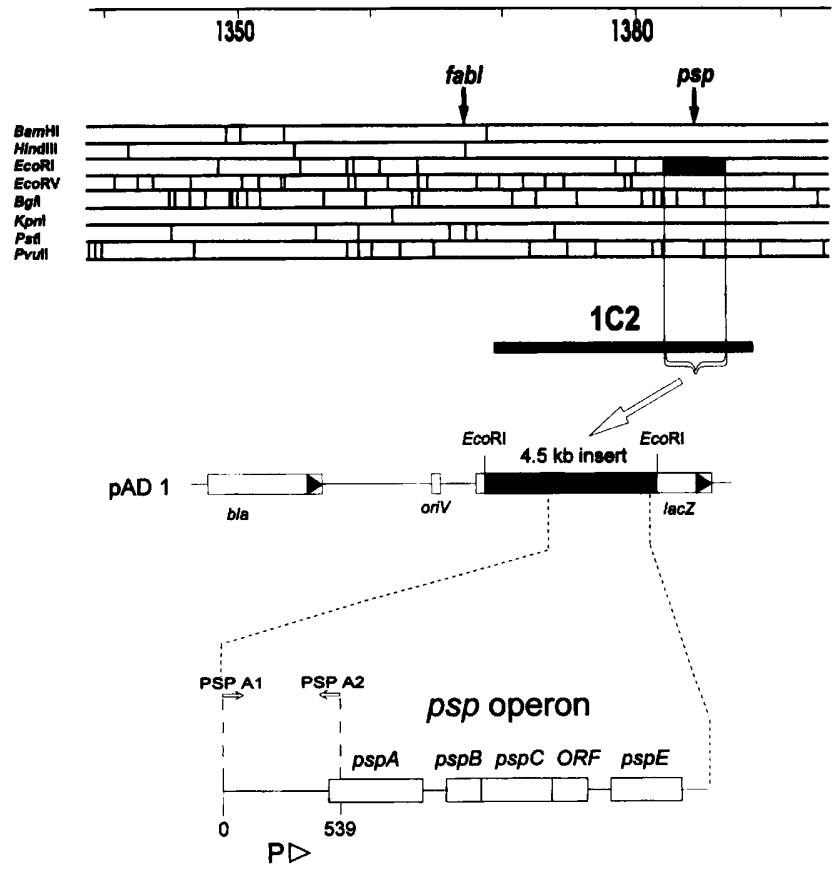

Fig. 2. Section of the physical map from 1340 to $1390 \mathrm{~kb}$ of the $E$. coli chromosome as described by Kohara et al. (1987). The locations of the fabl gene and the psp operon are indicated by arrows. 1C2 designates the recombinant $\lambda$ phage from the Kohara et al. (1987) collection that carries the psp operon. The $4.5 \mathrm{~kb}$ EcoRl fragment that hybridized to the synthetic oligonucleotide PSP A2 is shown in grey. The construction of PAD1 which comprised the $4.5 \mathrm{~kb}$ EcoRI fragment with the psp operon in pUC118 is illustrated below the restriction map. The insert DNA is shown as a grey bar. Below, the organization of the psp operon as published by Brissette et al. (1991) is shown. The putative promoter is marked with $P$ and the orientation of transcription with an open arrowhead at the bottom of the figure. PSP A1 and PSP A2 are the specific oligonucleotides used for the amplification of the 539 bp fragment containing the pspA promoter region.

contains the region spanning nucleotide 6 to nucleotide 530 of the DNA sequence of the $p s p$ operon including the promoter region of the $p s p A$ gene as published by Brissette et al. (1991). The nucleotide sequence of the PCR product was determined and was found to be identical to the published sequence except for the two base pair exchanges which had been introduced to create the EcoRI restriction sites for cloning purposes. E. coli cells containing the $p s p A-l a c Z$ fusion on the multi-copy plasmid pAD3 expressed extremely high $\beta$-galactosidase activity in the range of 8000 units, according to the method of Miller (1972). In order to assess the $p s p A$ promoter activity independently of the high copy number of pAD3 the $p s p A-l a c Z$ fusion was introduced into the $E$. coli chromosome as a single copy by infection with the recombinant phage $\lambda \phi \mathrm{AD} 3$ (Simons et al., 1987). The lysogen that carried the $p s p A-l a c Z$ fusion at the $\lambda$ attachment site attP in the chromosome was designated E. coli MC3. Chromosomal DNA of the lysogen MC3 was analysed by Southern hybridization with both a lacZspecific and a $p s p A$-promoter specific probe. The result 


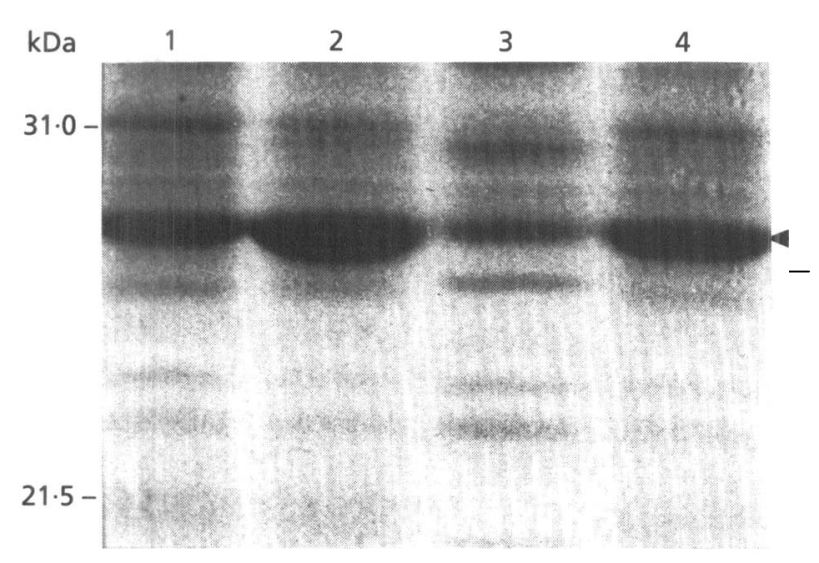

Fig. 3. Expression of the PspA protein from the recombinant plasmid pAD1. Cytoplasmic membrane proteins isolated from $E$. coli JP1111 treated with $20 \mu \mathrm{g}$ diazaborine $\mathrm{ml}^{-1}$ for $5 \mathrm{~h}$ at $30^{\circ} \mathrm{C}$ (lane 1), from $E$. coli JP1111 pAD1 grown in the presence of $20 \mu \mathrm{g}$ diazaborine $\mathrm{ml}^{-1}$ (lane 2), and $E$. coli JP1111 pAD1 grown at $30^{\circ} \mathrm{C}$ under non-inducing conditions (lane 3 ) were separated by SDS-PAGE on an $11 \%$ gel and stained with Coomassie Brilliant Blue. In lane 4 the extracts from lanes 1 and 2 were mixed to prove the identity of the proteins encoded by the chromosomal gene and the recombinant plasmid, respectively. The section of the stained polyacrylamide gel containing PspA is shown. The positions of two molecular mass markers are indicated. The position of PspA is marked with an arrow.

indicated that the $p s p A-l a c Z$ fusion was integrated in the chromosome of E. coli MC3 as a single copy.

\section{Induction of PspA by diazaborine treatment}

The $\beta$-galactosidase activity of the $p s p A-l a c Z$ fusion strain E. coli MC3 was around 100 units according to Miller (1972) and was independent of the growth phase (Fig. 4). When identical cultures of E. coli MC3 were incubated to early exponential phase at $30^{\circ} \mathrm{C}$, treated with 4 and $20 \mu \mathrm{g}$ diazaborine $\mathrm{ml}^{-1}$ and samples removed at various time points, a progressive increase in enzyme activity was measured (Fig. 4b). The extent of induction was dependent on the drug concentration. At the lower diazaborine concentration the $\beta$-galactosidase activity was induced 6-fold after $4 \mathrm{~h}$ incubation. During incubation with $20 \mu \mathrm{g}$ of diazaborine $\mathrm{ml}^{-1}$ the induction of PspA occurred earlier and the enzyme activity increased by a factor of 13. The degree of growth inhibition expressed as reduction in $\mathrm{OD}_{600}$ as compared to the untreated control was similar at both drug concentrations (Fig. 4a). Inhibition of an essential step in fatty acid biosynthesis, namely the enoyl-ACP reductase activity, by diazaborine, thus causes high expression of the PspA protein. However, in all experiments the induction of PspA synthesis started only 3-4 h after the addition of the drug, although we know from previous experiments that lipid synthesis is inhibited immediately after diazaborine addition (Turnowsky et al., 1989).

The induction of the $p s p A$ promoter was specific for the diazaborine action and not due to growth inhibition per se.
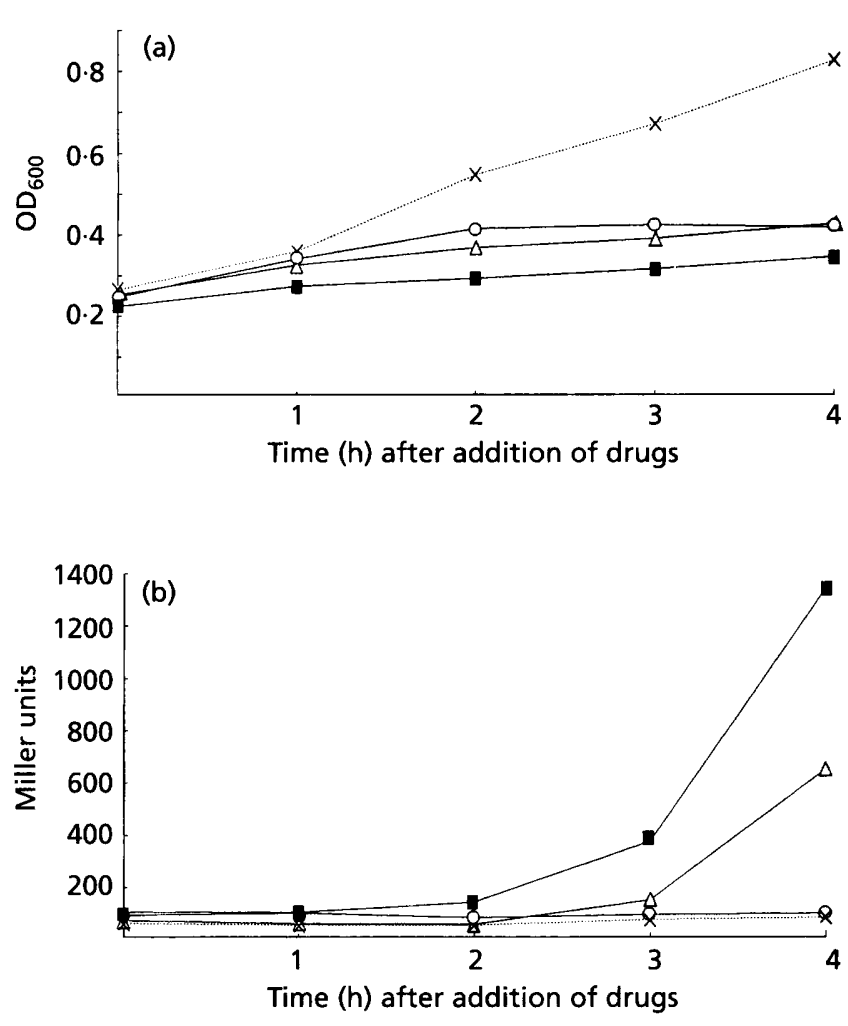

Fig. 4. Growth inhibition by diazaborine and nalidixic acid and induction of the pspA-lacZ fusion. (a) Growth curves of $E$. coli MC3 incubated in Minimal Medium $A$ at $30^{\circ} \mathrm{C}(x)$, at $30^{\circ} \mathrm{C}$ in the presence of $4 \mu \mathrm{g} \mathrm{ml}^{-1}(\triangle)$ and $20 \mu \mathrm{g} \mathrm{ml}^{-1}(\square)$ diazaborine or in the presence of $40 \mu \mathrm{g} \mathrm{ml}^{-1}$ of nalidixic acid $(O)$. Identical cultures were incubated at $30^{\circ} \mathrm{C}$ to early exponential phase before the addition of the drugs. (b) $\beta$-Galactosidase activity produced from the $p s p A$ promoter in the $p s p A-l a c Z$ construct in $E$. coli MC3 was measured at the indicated time points after addition of the drugs according to Miller (1972). Diazaborine and nalidixic acid were added to early exponential phase cultures (time zero) to final concentrations of $0 \mu \mathrm{g} \mathrm{ml}^{-1}(x)$ $4 \mu \mathrm{g} \mathrm{ml}^{-1}(\triangle)$ or $20 \mathrm{\mu g} \mathrm{ml}^{-1}(\mathbb{D})$ of diazaborine and $40 \mu \mathrm{g} \mathrm{ml}^{-1}$ of nalidixic acid $(O)$. The incubation continued for $4 \mathrm{~h}$ at $30^{\circ} \mathrm{C}$.

Nalidixic acid at a concentration of $40 \mu \mathrm{g} \mathrm{ml}^{-1}$ halted growth, but did not induce the $p s p A$ expression (Fig. $4 \mathrm{a}, \mathrm{b})$. This result is in accordance with published data (Brissette et al., 1990).

\section{Induction of PspA by cerulenin}

Cerulenin is a known inhibitor of 3-keto-acyl-ACP synthetase (D'Agnolo et al., 1973). As a consequence of the inhibition of fatty acid biosynthesis, phospholipid synthesis was reduced (Fig. 5). The incorporation of orthophosphate into phospholipids after $2 \mathrm{~h}$ incubation in the presence of $100 \mu \mathrm{g}$ cerulenin $\mathrm{ml}^{-1}$ was threefold lower than that measured in the absence of the drug. At the lower concentration, inhibition started later and was less pronounced. The effect of cerulenin on the growth of $E$. coli $\mathrm{K} 125 \mathrm{~K}$ is also shown in Fig. 5 . At $50 \mu \mathrm{g} \mathrm{ml}^{-1}$ growth was only slightly affected after $3 \mathrm{~h}$ incubation with the 


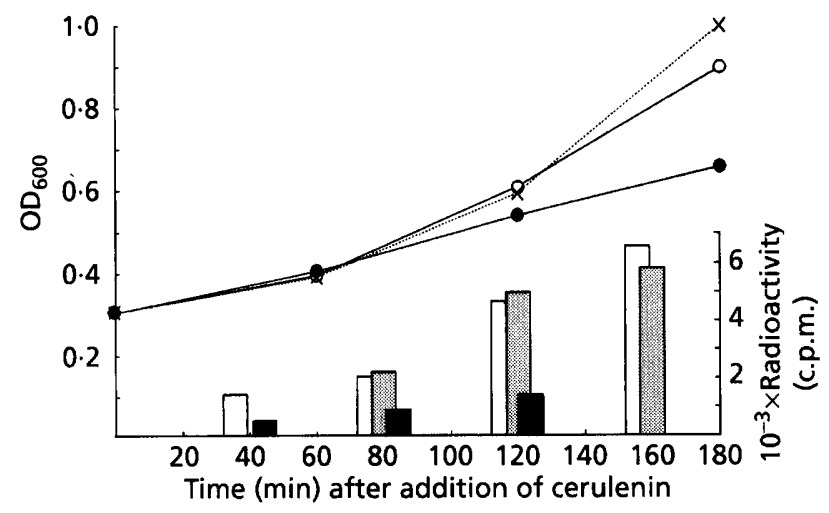

Fig. 5. Inhibition of growth and phospholipid synthesis in $E$. coli $\mathrm{K} 125 \mathrm{~K}$ by cerulenin. $E$. coli $\mathrm{K} 125 \mathrm{~K}$ was grown in phosphate-free medium at $30^{\circ} \mathrm{C}$. Identical cultures were grown to early exponential phase and $0(x), 50(O)$ and $100 \mu \mathrm{g} \mathrm{ml}^{-1}$ (O) of cerulenin were added (time zero). The incubation was continued for $3 \mathrm{~h}$ and the $O_{600}$ measured at the times indicated. Below the growth curves the incorporation of orthophosphate into phospholipids is shown. Cultures of $E$. coli $\mathrm{K} 125 \mathrm{~K}$ were grown as above. At $\mathrm{OD}_{600} 0.3$ (time zero) $10 \mu \mathrm{Ci}$ $(370 \mathrm{kBq})\left[{ }^{32} \mathrm{P}\right]$ orthophosphate were added to each culture and incubation continued for $3 \mathrm{~h}$ without antibiotic (open bars), in the presence of $50 \mathrm{\mu g} \mathrm{m}^{-1}$ (grey bars) or $100 \mu \mathrm{g} \mathrm{ml}^{-1}$ (black bars) cerulenin. Samples were removed at 40,80, 120, and $160 \mathrm{~min}$ after the simultaneous addition of radioisotope and drug. Phospholipids were extracted as described in Methods. The radioactivity contained in aliquots of the chloroform phases was determined.

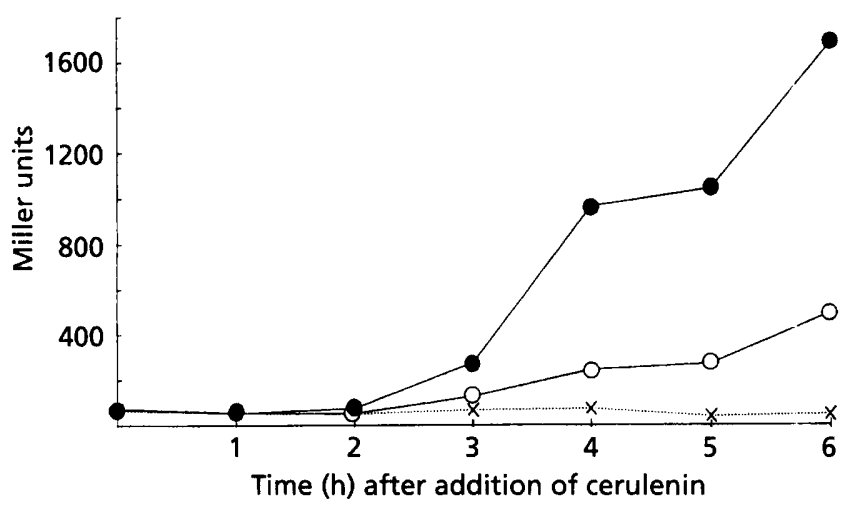

Fig. 6. Dose-dependent induction of the pspA promoter by cerulenin. Cerulenin was added at time zero to final concentrations of $50 \mu \mathrm{g} \mathrm{ml}^{-1}(O)$ and $100 \mu \mathrm{g} \mathrm{ml}^{-1}$ (O) to E. coli MC3 cultures grown in Minimal Medium A at $30^{\circ} \mathrm{C}$ to early exponential phase and incubation continued for $6 \mathrm{~h}$. Samples were removed at the indicated time points and the $\beta$ galactosidase activity determined as described. As a control, an identical culture without drug was tested $(x)$.

drug as compared to the untreated control culture. At $100 \mu \mathrm{g}$ cerulenin $\mathrm{ml}^{-1}$, growth was strongly inhibited upon prolonged incubation without lysis of the cells.

Fig. 6 indicates the effect on $\beta$-galactosidase activity expressed by E. coli MC3 in response to incubation with

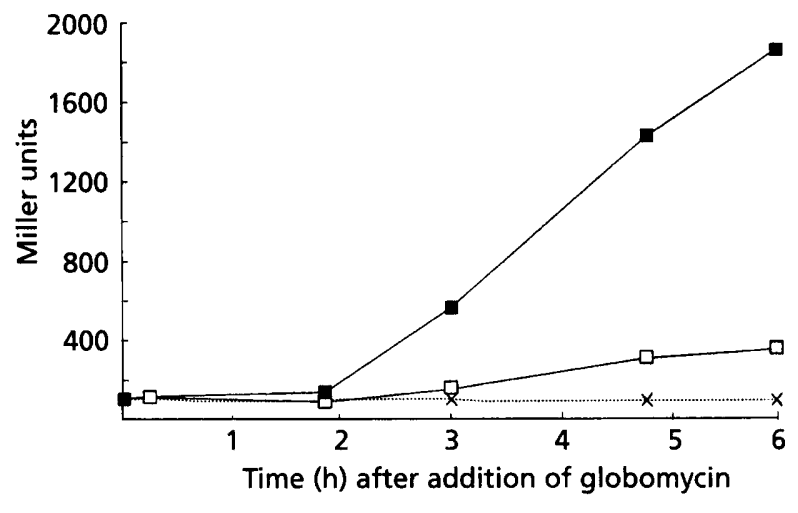

Fig. 7. Induction of pspA promoter by globomycin. Globomycin was added to early exponential phase cultures of $E$. coli MC3 (time zero) to final concentrations of $10 \mu \mathrm{g} \mathrm{ml}^{-1}$ ( $\square$ ) and $50 \mu \mathrm{g} \mathrm{ml}^{-1}$ ( $\square$ ) and incubation continued for $6 \mathrm{~h}$ at $30^{\circ} \mathrm{C}$. An untreated culture $(x)$ served as a control.

50 and $100 \mu \mathrm{g}$ cerulenin $\mathrm{ml}^{-1}$. Cerulenin treatment at 50 $\mu \mathrm{g} \mathrm{m}{ }^{-1}$ only slightly induced PspA synthesis; the reporter enzyme activity increased 3-6-fold during $6 \mathrm{~h}$ incubation. However, at $100 \mu \mathrm{g} \mathrm{ml}^{-1}$ we observed a strong induction of transcriptional activity from the $p s p A$ promoter that reached 17 times the uninduced level. The degree of induction of PspA synthesis was dependent on inhibition of growth, inhibition of phospholipid biosynthesis and correlated with the concentration of the drug. Again, the onset of induction was delayed as already observed after diazaborine treatment. Thus, the kinetics of induction by both cerulenin and diazaborine are almost identical.

\section{Induction of PspA expression by globomycin}

In order to examine PspA expression under conditions which block translocation of certain proteins through the cytoplasmic membrane we tested globomycin as a potential inducer. Globomycin is an inhibitor of the E. coli signal peptidase II which is specific for the processing of prolipoproteins (Inukai et al., 1978a, b). When E. coli MC3 was incubated with $50 \mu \mathrm{g}$ globomycin $\mathrm{ml}^{-1}$ cell growth was inhibited and transcriptional activity from the psp $A$ promoter was strongly induced, up to 20 times above the basal level during $6 \mathrm{~h}$ incubation (Fig. 7). At the lower concentration of $10 \mu \mathrm{g}$ globomycin $\mathrm{ml}^{-1}$ the induction of PspA expression was only threefold above the untreated control.

\section{Other conditions of PspA induction}

Brissette et al. (1990) showed that the expression of the PspA protein was induced by extreme stress conditions and by infection of $E$. coli with the filamentous phage $f 1$. In order to test the inducibility of the $p s p A-l a c Z$ fusion, $E$. coli MC3 R1-16 was infected with the male-specific filamentous phage M13. The $\beta$-galactosidase activity expressed by this strain was measured at various times after infection. As shown in Fig. 8 the enzyme activity 


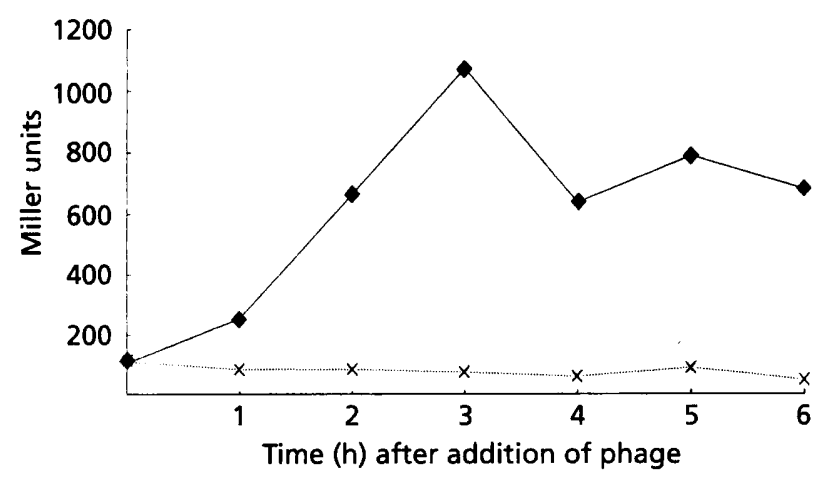

Fig. 8. Influence of phage M13 infection on pspA expression. The $\beta$-galactosidase activity expressed by $E$. coli MC3 R1-16 was determined as described. Phage M13 was added at a multiplicity of 10 to an early exponential phase culture of $\mathrm{OD}_{600}$ 0.3 (time zero) and the incubation continued for $6 \mathrm{~h}$ at $30^{\circ} \mathrm{C}$ $(\diamond)$. As a control an identical culture of $E$. coli MC3 R1-16 without phage was used $(x)$.

increased during infection with phage M13. The maximum was reached at $3 \mathrm{~h}$ of infection, at which time the enzyme activity was approximately 10 times higher than in the uninfected control. During longer incubation with the phage, expression of the $p s p A$ gene decreased slowly but stayed well above the uninduced control level.

We also tested whether the induction of PspA was mediated by alarmones. These compounds are known to accumulate upon incubation of $E$. coli cells at high temperature, in the presence of ethanol, or when incubated with oxidizing agents, like hydrogen peroxide or naphthochinon (Lee et al., 1983; Bochner et al., 1984). Over an incubation period of $4 \mathrm{~h}$ in the presence of $70 \mu \mathrm{g}$ hydrogen peroxide $\mathrm{ml}^{-1}$ or $100 \mu \mathrm{g}$ naphthochinon $\mathrm{ml}^{-1}$ we did not observe any induction of $\beta$-galactosidase in $E$. coli MC3 (data not shown). Thus, the effect of ethanol and high temperature on PspA synthesis is not mediated by alarmones.

\section{Cell morphology}

As described previously, treatment of $E$. coli cells with diazaborine results in a detachment of the cytoplasmic membrane predominantly at the cell poles (Turnowsky $e t$ al., 1989). We observed exactly the same morphological changes when cells were treated with cerulenin at concentrations that severely inhibited phospholipid biosynthesis (data not shown). Interestingly, globomycin treatment also induces the retraction of the cytoplasmic membrane at the poles of E. coli cells (data not shown), although the antibiotic has a completely different mode of action and leads to the formation of large spheroplasts (Inukai et al., 1978a).

\section{DISCUSSION}

We have identified the $28 \mathrm{kDa}$ protein that is strongly expressed during incubation of $E$. coli with diazaborine (Turnowsky et al., 1989). It is identical to the recently described phage shock protein PspA (Brissette et al.,
1991). Based on P1 transduction data of Brissette et al. (1991) we localized the $p s p A$ gene on the recombinant phage $\lambda 1 \mathrm{C} 2$ and assigned its exact position on the $E$. coli chromosome to coordinate $1384 \mathrm{~kb}$ of the Kohara et al. (1987) physical map. It is thus closely linked to the $f a b I$ gene which maps at $1366.8 \mathrm{~kb}$ (Bergler et al., 1992).

The PspA protein is associated with the cytoplasmic membrane and its synthesis is induced during infection with filamentous phages or when $E$. coli undergoes extreme stress conditions, such as incubation at $50^{\circ} \mathrm{C}$ or in the presence of $10 \%$ ethanol (Brissette et al., 1990). Similar incubation conditions are known to induce alarmones (Lee et al., 1983). Our results, however, show that those alarmones which accumulate upon treatment with hydrogen peroxide and naphthochinon are not related with PspA synthesis. Since incubation at high temperature or in the presence of ethanol leads to the accumulation of the same alarmones as treatment with the oxidizing agents, the induction of PspA expression does not seem to proceed via alarmones.

Globomycin is an antibiotic that specifically inhibits signal peptidase II and thus leads to the accumulation of precursor forms of lipoproteins in the cytoplasmic membrane (Ichihara et al., 1981). We now show that incubation of E. coli cells with globomycin strongly induces PspA expression. Induction of PspA was recently demonstrated for mutations affecting protein translocation (Kleerebezem \& Tommassen, 1993; Carlson \& Silhavy, 1993) and when large amounts of phage protein IV and other homologous proteins were integrated into the outer and cytoplasmic membranes of E. coli (Brissette et al., 1990; Russel \& Kazmierczak, 1993). Carlson \& Silhavy (1993) have proposed that processing-defective outermembrane proteins, like LamBA23D, span both inner and outer membranes and, when expressed in large amounts, affect the integrity of the envelope. As a consequence PspA synthesis is strongly induced. A truncated form of the mutant LamBA23D protein and an unprocessed form of the periplasmic MalE protein are tethered only in the inner membrane and thus fail to induce PspA synthesis. On the other hand, Kleerebezem \& Tommassen (1993) suggest that accumulation of precursors within the membrane translocation complex is sufficient to induce PspA synthesis. Although these two hypotheses exist in the literature we favour the model that accumulation of unprocessed prolipoproteins after incubation of $E$. coli with globomycin could disrupt the integrity of the envelope analogous to LamBA23D.

Diazaborine treatment of $E$. coli is another novel and specific cause for induction of PspA expression. Diazaborine inhibits fatty acid biosynthesis by interfering with the NADH-dependent enoyl-ACP reductase of $E$. coli (Bergler et al., 1994). Another inhibitor of fatty acid synthesis is cerulenin. A block in fatty acid biosynthesis by either antibiotic leads to inhibition of phospholipid synthesis and to strong induction of PspA. The increase in psp $A$ gene expression correlates well with the degree of inhibition of phospholipid synthesis by both diazaborine and cerulenin, although the onset of induction is delayed. Inhibition of fatty acid biosynthesis certainly leads to 
changes in membrane integrity which we have demonstrated microscopically as retraction of the cytoplasmic membrane after treatment of $E$. coli with diazaborine (Turnowsky et al., 1989). Impaired phospholipid biosynthesis is a consequence of the block in fatty acid biosynthesis and might directly interfere with protein translocation and, thus, induce PspA synthesis or, more generally, causes severe membrane perturbations that might trigger a so far unidentified signal for subsequent induction of the PspA protein. This signal could be common also to other stress conditions that have already been known to induce PspA synthesis. Further experiments are needed to distinguish between these two alternatives.

\section{ACKNOWLEDGEMENTS}

We are grateful to Yuji Kohara for providing the recombinant phage $\lambda 1 \mathrm{C} 2$, to Robert W. Simons for supplying plasmid pRS591, and to Sankyo for a gift of globomycin. We thank Tom Silhavy for his support in the early stage of this work. We gratefully acknowledge Gregor Högenauer and Ellen Zechner for helpful discussions and suggestions on the manuscript. This work was supported by the Fonds zur Förderung der wissenschaftlichen Forschung, grant no. P7939.

\section{REFERENCES}

Ausubel, F. M., Brent, R., Kingston, R. E., Moore, D. D., Smith, J. A., Seidman, J. G. \& Struhl, K. (1987). Current Protocols in Molecular Biology. New York: John Wiley.

Bergler, H., Högenauer, G. \& Turnowsky, F. (1992). Sequences of the envM gene and of two mutated alleles in Escherichia coli. $J$ Gen Microbiol 138, 2093-2100.

Bergler, H., Wallner, P., Ebeling, A., Leitinger, B., Fuchsbichler, S., Turnowsky, F. \& Högenauer, G. (1994). Protein EnvM is the NADH dependent enoyl-ACP reductase (FabI) of Escherichia coli. $J$ Biol Cbem 269, 5495-5496.

Bochner, B. R., Lee, P. C., Wilson, S. W., Cutler, C. W. \& Ames, B. N. (1984). AppppA and related adenylylated nucleotides are synthesized as a consequence of oxidation stress. Cell 37, 225-232.

Bradford, M. M. (1976). A rapid and sensitive method for the quantitation of microgram quantities of protein utilizing the principle of protein-dye binding. Anal Biochem 72, 248-254.

Brissette, J. L., Russel, M., Weiner, L. \& Model, P. (1990). Phage shock protein, a stress protein of Escherichia coli. Proc Natl Acad Sci US A 87, 862-866.

Brissette, J. L., Weiner, L., Ripmaster, T. L. \& Model, P. (1991). Characterization and sequence of the Escherichia coli stress-induced psp operon. J Mol Biol 220, 35-48.

Carlson, J. H. \& Silhavy, T. J. (1993). Signal sequence processing is required for the assembly of LamB trimers in the outer membrane of Escherichia coli. J Bacteriol 175, 3327-3334.

Casabadan, M. J. \& Cohen, S. N. (1980). Analysis of gene control signals by DNA fusion and modification of DNA in Escherichia coli. J Mol Biol 138, 179-207.

D'Agnolo, G., Rosenfeld, I. S., Awaya, J., Omura, S. \& Vagelos, P. R. (1973). Inhibition of fatty acid synthesis by the antibiotic cerulenin. Specific inactivation of $\beta$-ketoacyl-acyl carrier protein synthetase. Biochim Biophys Acta 326, 155-166.
Egan, A. F. \& Russell, R. R. B. (1973). Conditional mutants affecting the cell envelope of E. coli K12. Genet Res 21, 139-152.

Garen, A. \& Levinthal, C. (1960). A fine-structure genetic and chemical study of the enzyme alkaline phosphatase of E. coli. I. Purification and characterization of alkaline phosphatase. Biochim Biophys Acta 38, 470-483.

Grassberger, M. A., Turnowsky, F. \& Hildebrand, J. (1984). Preparation and antibacterial activities of the 1,2,3-diazaborine derivatives and analogues. $J$ Med Chem 27, 947-953.

Högenauer, G. \& Woisetschläger, M. (1981). A diazaborine derivative inhibits lipopolysaccharide biosynthesis. Nature 293, 662-664.

Ichihara, S., Hussain, M. \& Mizushima, S. (1981). Characterization of new membrane lipoproteins and their precursors of Escherichia coli. J Biol Chem 256, 3125-3129.

Inukai, M., Nakajima, M., Osawa, M., Haneishi, T. \& Arai, M. (1978a). Globomycin, a new peptide antibiotic with spheroplastforming activity. II. Isolation and physico-chemical and biological characterization. I Antibiot 31, 421-425.

Inukai, M., Takeuchi, M., Shimizu, K. \& Arai, M. (1978b). Mechanism of action of globomycin. J Antibiot 31, 1203-1205.

Kleerebezem, M. \& Tommassen, J. (1993). Expression of the $p s p . A$ gene stimulates efficient protein export in Escherichia coli. Mol Microbiol 7, 947-956.

Kohara, Y., Akiyama, K. \& Isono, K. (1987). The physical map of the whole E. coli chromosome. Application of a new strategy for rapid analysis and sorting of a large genomic library. Cell $\mathbf{5 0}$, 495-508.

Lee, P. C., Bochner, B. R. \& Ames, B. N. (1983). Diadenosine 5', $5^{\prime \prime \prime}$ $\mathrm{P}^{1}, \mathrm{P}^{4}$-tetraphosphate and related adenylylated nucleotides in $\mathrm{Sal}$ monella typbimurium. J Biol Chem 258, 6827-6834.

Miller, J. H. (1972). Experiments in Molecular Genetics. Cold Spring Harbor, NY: Cold Spring Harbor Laboratory.

Russel, M. \& Kazmierczak, B. (1993). Analysis of the structure and subcellular location of filamentous phage pIV. J Bacteriol 175, 3998-4007.

Sambrook, J., Fritsch, E. F. \& Maniatis, T. (1989). Molecular Cloning: a Laboratory Manual, 2nd edn. Cold Spring Harbor, NY: Cold Spring Harbor Laboratory.

Sanger, F., Nicklen, S. \& Coulsen, A. R. (1977). DNA sequencing with chain terminating inhibitors. Proc Natl Acad Sci US A 74, 5463-5467.

Silhavy, T. J., Berman, M. L. \& Enquist, L. W. (1984). Experiments with Gene Fusions. Cold Spring Harbor, NY: Cold Spring Harbor Laboratory.

Simons, R. W., Houman, F. \& Kleckner, N. (1987). Improved single and multicopy lac-based cloning vectors for protein and operon fusions. Gene 53, 85-96.

Turnowsky, F., Fuchs, K., Jeschek, C. \& Högenauer, G. (1989). envM genes of Salmonella typhimurium and Escherichia coli.J Bacteriol 171, 6555-6565.

Vieira, J. \& Messing, J. (1987). Production of single-stranded plasmid DNA. Methods Enzymol 153, 3-11.

Weiner, L., Brissette, J. L. \& Model, P. (1991). Stress-induced expression of the Escherichia coli phage shock protein operon is dependent on $\sigma^{54}$ and modulated by positive and negative feedback mechanisms. Genes Dev 5, 1912-1923.

Received 10 January 1994; accepted 14 March 1994. 